\title{
Germination, initial growth, and biomass allocation in three native Cerrado species
}

\author{
PABLO SABOYA ${ }^{1}$ and FABIAN BORGHETTI ${ }^{1,2}$
}

(received: December 11, 2011, accepted: May 07, 2012)

\begin{abstract}
Germination, initial growth, and biomass allocation in three native Cerrado species). The parameters of germination, initial growth, and biomass allocation of three native plant species of Cerrado (Copaifera langsdorffi, Dipteryx alata and Kielmeyera coriacea) were established. The species had germination percentages above $88 \%$ and average germination times longer than 139 hours. The average time for the opening of the first leaf pair was more than 538 hours for all three species. The average root length of $C$. langsdorffi and D. alata seedlings after 80 days of growth was around $40 \mathrm{~cm}$, four times larger than the average shoot length $(<10 \mathrm{~cm})$, although the root and shoot biomasses were similar for both species. The average root length $(>20 \mathrm{~cm})$ of $K$. coriacea seedlings was four times larger than the average shoot length $(<5 \mathrm{~cm})$, and the root biomass was $243 \%$ greater than the shoot biomass. Increase in seedling biomass was sustained primarily by the cotyledons in $C$. langsdorffi and $D$. alata, which acted as reserve organs and showed progressive weight reductions. Increase in seedling biomass in $K$. coriacea was sustained primarily by photosynthesis, since the cotyledons showed no significant weight reduction, acting primarily as photosynthetic organs. The length of the root systems was at least four times larger than the length of the shoots parts in all three species. Higher investment in root length rather than in root biomass suggest that the initial growth of these species is primarily to ensure access to water resources, apparently putting off the function of the radicular system as storage organ.
\end{abstract}

Key words - biomass partitioning, Copaifera langsdorffi, Dipteryx alata, Kielmeyera coriacea, seedling growth

\section{INTRODUCTION}

The Cerrado vegetation (Brazilian savanna) is characterized by the seasonality of both temperature and precipitation during the year, with cold and dry winters and hot and humid summers (Eiten 1972, Ribeiro \& Walter 2008). The climate is classified as Aw by the Köppen system (tropical rainy), with average annual rainfall near $1500 \mathrm{~mm}$ and average annual temperatures varying from 18 to $28^{\circ} \mathrm{C}$ (Silva et al. 2008). The Cerrado shows a wide variety of physiognomies, including open field formations dominated by herbaceous species, savanna formations, with a well-developed herbaceous-shrub layer and sparse trees, to forest physiognomies formations with a well-developed arboreal component (Oliveira Filho \& Ratter 2002). This gradient is affected and determined by diverse environmental agents such as temperature, water availability, depth of the water table, fire frequencies, anthropogenic disturbances, and edaphic factors (Coutinho 1978, Ribeiro \& Walter 2008).

Among the factors limiting the initial establishment of Cerrado species the soil-water deficit is one of the most important. During the rainy season, the soil water

\footnotetext{
1. Universidade de Brasília, Departamento de Botânica, Laboratório de Termobiologia, Campus Universitário Darcy Ribeiro, 70919-970 Brasília, DF, Brazil.

2._Corresponding author: fborghet@unb.br
}

potential $(\psi s)$ remains very near the field capacity $(\psi \mathrm{s}=-0.06 \mathrm{MPa})$ but can become much more negative during the veranicos (periods without rainfall during the rainy season), reducing water availability at depths up to $15 \mathrm{~cm}$ (Kanegae et al. 2000). During the dry season, the $\Psi$ s is reduced considerably, reaching values up to $-6.2 \mathrm{MPa}$ at depths of $5 \mathrm{~cm}$ and $-2.6 \mathrm{MPa}$ at depths of $60 \mathrm{~cm}$ in the campo sujo (savanna-like vegetation) physiognomy. In the cerradão (forest-like vegetation) the minimum $\Psi_{\mathrm{s}}$ at the same depths were -2.8 and -1.8 MPa respectively (Kanegae et al. 2000). These conditions restrict the establishment of drought-sensitive species, and consequently favor and select for species tolerant to water deficit.

Savanna species tend to invest more in deep roots, which make them less susceptible to soil water deficits than forest species (Hoffmann et al. 2004). Savanna species also tend to invest more in subterranean biomass than forest species, which gives them a greater resprouting capacity and therefore greater resistance to fires (Hoffmann 2000); savanna species usually invest more in subterranean biomass than in shoot biomass (Haridasan 2000). It has long been thought that the rapid root growth of savanna species and the formation of reserve organs are strategies that facilitate the survival of these plants during the long dry season (Labouriau et al. 1963).

The reserve tissues of the seedlings have a fundamental role in their initial growth, and these reserves can be determinant of the seedling recruitment 
under natural conditions, particularly in environments where the light intensity is low, or demand a rapid initial growth (Melo et al. 2004). Also, it is known that there is a direct relationship between diaspore reserve mobilization and the stablishment of the photosynthetic apparatus in seedlings; indeed, if the cotyledons have a primary photosynthetic function they tend to remain for longer periods of time attached to the seedlings (Kitajima 1994, Melo et al. 2004, Ressel et al. 2004). For example, the cotyledons of Kielmeyera coriacea remain attached to the seedlings for approximately one year, suggesting that they have important role in the initial growth of this species (Nardoto et al. 1998). Despite their important role in the seedling growth, there is still relatively little information available about the physiological and biochemical aspects of cotyledons functions and the mechanisms of seed reserve mobilization for tree seedlings (Zaidan \& Carreira 2008).

In a comparative study of species occurring in different Cerrado physiognomies, Moreira \& Klink (2000) analyzed the patterns of initial growth and biomass allocation of species from cerradão and from cerrado sensu stricto physiognomies, as well as in species common to both phytophysiognomies. These authors did not identify any consistent differences between the cerradão and cerrado sensu stricto species in terms of the ratio of biomass allocation between the root and shoot parts (root shoot $^{-1}$ ratio); among the 10 species studied, five allocated more biomass to the roots (root shoot ${ }^{-1}>1.5$ ) and five allocated similar biomasses to roots and shoots (root shoot $^{-1} \sim 1$ ), or allocated less biomass to the roots than to the shoot parts of the plant (root shoot ${ }^{-1} \leq 1$ ) (Moreira $\&$ Klink 2000). Although they could not determine any correlation of the ratios of biomass allocation between the roots and shoots with the physiognomies of occurrence of the species, these authors noted that all of the species showed accentuated elongation of the roots during their initial growth period (Moreira \& Klink 2000). In particular, they found that Kielmeyera coriacea, a species typical of cerrado sensu stricto allocated considerably more biomass to the roots in relation to the shoot parts of the plants (root shoot ${ }^{-1} \sim 9$ ).

In order to contribute to a better understanding of the eco-physiology of the initial growth of Cerrado species, the present study examined the parameters of germination, initial growth, and biomass partitioning in three plant species widely distributed in the Cerrado vegetation: Kielmeyera coriacea, Copaifera langsdorffii, and Dipteryx alata. All of these species occur in cerrado sensu stricto and cerradão, although $K$. coriacea also occurs in campo sujo vegetation; $C$. langsdorffi $i$ and $D$. alata also both occur in dry forests, and C. langsdorffii can also be found in gallery forests (Almeida et al. 1998, Silva Júnior 2005).

\section{MATERIAL AND METHODS}

\section{Species characterization and seed collection and storage}

Copaifera langsdorffii Desf. (Fabaceae Caesalpinioideae) seeds were collected from at least five adult trees during November/2008 in the Darcy Ribeiro campus at the Universidade de Brasília, DF, Brazil (1548'00" S; $\left.47^{\circ} 51^{\prime} 50^{\prime \prime} \mathrm{W}\right)$ and were stored at room temperature $\left(22-24^{\circ} \mathrm{C}\right)$ until April/2009. Before the beginning of the experiments the seeds were immersed in $2 \%$ sodium hypochlorite, stirred for 2 minutes, and subsequently rinsed with running tap water for 30 seconds.

Dipteryx alata Vogel (Fabaceae - Faboideae) fruits were collected from at least 10 adult trees between August and October/2008 in the municipality of Cavalcante, Goiás State (GO) $\left(13^{\circ} 47^{\prime} 52^{\prime \prime} \mathrm{S} ; 47^{\circ} 51^{\prime} 50^{\prime \prime} \mathrm{W}\right)$; the fruits were carefully broken in a vise to remove the seeds. The seeds were stored in cotton sacks at room temperature $\left(22-24{ }^{\circ} \mathrm{C}\right)$ until April/2009. Before the beginning of the experiments the seeds were immersed in $2 \%$ sodium hypochlorite, stirred for 2 minutes, and subsequently rinsed in running tap water for 30 seconds.

Kielmeyera coriacea (Spreng.) Mart. (Clusiaceae) seeds were collected from the dehiscent fruits of at least 10 adult plants occurring in a preserved native area on the Darcy Ribeiro campus at the Universidade de Brasília, DF (1548'00" S; 47 51'50" W) in August/2008. The seeds were stored at $-18{ }^{\circ} \mathrm{C}$ until April/2009.

\section{Dry weight, fresh weight, and seed germination}

The fresh and dry weights and water content of the seeds were determined by drying them in a forced air drying oven at $90{ }^{\circ} \mathrm{C}$ for 24 hours $(N=20$ seeds per species).

The experiments were initiated in April/2009. The germination tests were conducted in germination chambers (Marconi MA 403) under a 12 hour photoperiod at $30^{\circ} \mathrm{C} \mathrm{(a}$ temperature that lies within the temperature range appropriated for the germination of numerous Cerrado species) (Zaidan \& Carreira 2008). It was employed threes replicates of 40 seeds for $K$. coriacea, two replicates of 80 seeds for $C$. langsdorffi $i$, and two replicates of 50 seeds for $D$. alata. The seeds were considered as germinated if they emitted a radicle followed by its typical geotropic curvature (Labouriau 1983). Germination was evaluated daily to count and remove germinated seeds, and at the end of the experimental period the germinability ( $\mathrm{G}$, in percentage), the average germination time (AGT, in hours), and its standard deviations (SD, in hours) were calculated for each species (Labouriau 1983). 
The germinated seeds were used for experiments examining the initial growth.

\section{Initial growth}

Field experiments were conducted in a small reserve area of cerrado sensu stricto located near the Laboratório de Termobiologia L. G. Labouriau and the seedlings were allowed to grow under natural conditions, without tree or shrub shading (table 1).

Table 1. Maximum and minimum temperatures, humidity, precipitation, and total illumination for the Federal District region from April to July/2009.

\begin{tabular}{lllll}
\hline \multicolumn{1}{c}{ Averages } & \multicolumn{1}{c}{ April } & \multicolumn{1}{c}{ May } & \multicolumn{1}{c}{ June } & July \\
\hline Max. temperature $\left({ }^{\circ} \mathrm{C}\right)$ & $28-31$ & $25-28$ & $25-28$ & $28-31$ \\
Min. temperature $\left({ }^{\circ} \mathrm{C}\right)$ & $18-21$ & $15-18$ & $15-18$ & $12-15$ \\
Humidity $(\%)$ & $70-75$ & $70-75$ & $60-70$ & $50-60$ \\
Precipitation (mm) & $180-240$ & $30-50$ & $10-30$ & 0 \\
Total illumination (h) & $150-180$ & $180-220$ & $220-250$ & $250-300$ \\
\hline
\end{tabular}

Source: INMET.

The germinated seeds were transferred to PVC tubes $10 \mathrm{~cm}$ in diameter and $60 \mathrm{~cm}$ long filled with dystrophic Red Latosol (from $20 \mathrm{~cm}$ below the soil surface) gathered from the reserve area near the laboratory. The seedlings were watered daily. Samples of 20 individuals of each species were collected at intervals of 20,30,50 and 80 days after germination for biometric measurements. The average growth of the roots and shoots were measured, as well as the root and shoot dry weights (after drying at $80^{\circ} \mathrm{C} / 24 \mathrm{~h}$ ). Indeed, the average time required for the complete opening of the first pair of leaves (TLO, in hours) was calculated, as well as its standard deviation (SD, in hours). The criterion of initial growth was defined as the time between the beginning of the experiments (as the initial time) and the appearance of a fully expanded and completely formed leaf (final time).

\section{RESULTS AND DISCUSSION}

The seeds of Copaifera langsdorffii had average fresh weight of 0.94 grams and their water content was estimated to be $11.5 \%$; the seeds of Dipteryx alata had fresh weight of 1.34 grams and their water content was estimated to be $7.6 \%$; the seeds of Kielmeyera coriacea had fresh weight of 0.13 grams and their water content was estimated to be $3.9 \%$. The seeds of the three species investigated can be classified in terms of their water contents as "orthodox" (Villela \& Peres 2004). Although they have low water contents, seeds of $K$. coriacea have showed very short longevity; freezing them at $-18^{\circ} \mathrm{C}$ helped to maintain their germinability for more than six months without significantly effect on their germination characteristics (unpublished results).

The seeds of all three species showed germinability above $88 \%$ under controlled conditions (table 2), indicating the absence of dormancy or restrictions to germination. All of the species showed average germination times (AGT) above 120 hours (more than five days) (table 2). The species that showed the smallest AGT and SD among the three species studied was Dipteryx alata, thus being classified as the species with the most rapid and uniform germination in respect to the other two species (Santana \& Ranal 2004).

Table 2. Seed germination and initial growth parameters of Copaifera langsdorffii (copaíba), Dipteryx alata (baru), and Kielmeyera coriacea (pau-santo). Numbers of individuals per treatment $(N)$, Germinability $(\mathrm{G})$, Average germination time (AGT), Average time for opening of the first leaf pair (TLO) and their respective standard deviations (SD). Germination experiments were conducted at $30^{\circ} \mathrm{C}$ with a 12 hour photoperiod; initial growth was conducted under field conditions without shading. Average values in the same column, identified by the same letter, do not differ significantly according to the Kruskal-Wallis test followed by the Mann-Whitney test $(P<0.05)$.

\begin{tabular}{lccccccc}
\hline Species & $N$ & $\begin{array}{c}\text { G } \\
(\%)\end{array}$ & $\begin{array}{c}\text { AGT } \\
(\mathrm{h})\end{array}$ & $\begin{array}{c}\text { SD AGT } \\
(\mathrm{h})\end{array}$ & $\begin{array}{c}\text { TLO } \\
(\mathrm{h})\end{array}$ & $\begin{array}{c}\text { SD TLO } \\
(\mathrm{h})\end{array}$ \\
\hline Copaíba & 160 & $89.4 \mathrm{~b}$ & $408.0 \mathrm{~b}$ & 120.3 & 80 & 956.40 & 58.34 \\
Baru & 100 & $96.0 \mathrm{a}$ & $139.2 \mathrm{a}$ & 25.0 & 80 & 538.50 & 55.18 \\
Pau-santo & 120 & $88.3 \mathrm{~b}$ & $260.1 \mathrm{c}$ & 78.0 & 80 & - & - \\
\hline
\end{tabular}

According to Ferreira et al. (2001), the average germination time is a good measure for evaluating the rapidity with which a given species can occupy a certain environment, and it can be used to classify seed germination into three general categories: rapid (AGT < 120hours), intermediate(120hours < AGT < 240 hours); and slow (AGT $>240$ hours). So, in the present study (table 2), the germination of $D$. alata seeds can be classified as between rapid and intermediate; the germination of $K$. coriacea seeds as intermediate to slow; and the germination of $C$. langsdorffi seeds can be classified as slow (Ferreira et al. 2001).

Slow and spread germination over time is normally associated with species that occur in environments with unpredictable and/or seasonal climates, and this germination pattern has been considered as a strategy for plant establishment in environments where conditions are not always favorable (and/or predictable) to seedling growth (Leck et al. 1989, Doussi and Thanos 2002, Silva 
et al. 2010). This germination pattern has been described as "bet-hedging" or "delayed germination" (Venable 2007, Ooi et al. 2009), and it is supposed to reduce the probability that an entire cohort of seeds germinate in response to an environmental stimuli at an inappropriate moment for the subsequent seedling growth (such as an erratic and sporadic rain during the dry season). Slow and time-spaced germination also contributes to persistence of seeds in the soil seed bank (Saatkamp et al. 2011), an important attribute for the recruitment of new individuals in environments characterized by an unpredictable climate.

In the Cerrado biome, savanna physiognomies are more often subject to environmental stress than are forest physiognomies; thermal amplitudes in forests tend to be smaller and water availability and soil humidity tend to be more stable than in open savanna areas (Kanegae et al. 2000). As such, the slow and/or temporally distributed germination of $C$. langsdorffii and $K$. coriacea seeds are apparently part of a germination strategy that contributes to successful recruitment of theses species in savanna physiognomies of the Cerrado. In fact, both species are documented to be widely distributed in savanna formations of this large Brazilian biome (Almeida et al. 1998, Silva Júnior 2005).

Individuals of $C$. langsdorffii were shown to present greater root than shoot elongation during their first 80 days of growth. The seedling dry weight increased steadly but was essentially similar for both the shoot and root parts (figure 1). The shoot parts were quite uniform among the different specimens, with an average of eight leaflets per individual. The root system presented a long pivotal root and numerous lateral roots, these being shorter at shallow depths.

Seventeen-month-old individuals of $C$. langsdorffii exposed to different levels of shading were found to concentrate between 51 and $75 \%$ of their total biomass in the root system (Salgado et al. 2001). In the present study we found similar biomass partition between root and shoot parts during the first 80 days of growth, but the average root length was four times larger than the average shoot length, suggesting more investment in root elongation than in root biomass by this species.

A growth pattern similar to that described for C. langsdorffii was also seen in D. alata (figure 2). Morphologically, D. alata seedlings demonstrated homogeneity in the size of their shoot parts and in the quantities of leaves, with an average of 18 leaflets after 30 days and 24 leaflets after 80 days of growth. The roots were pivotal and long, and the lateral roots long, thick, and numerous along its entire extension. As $D$.
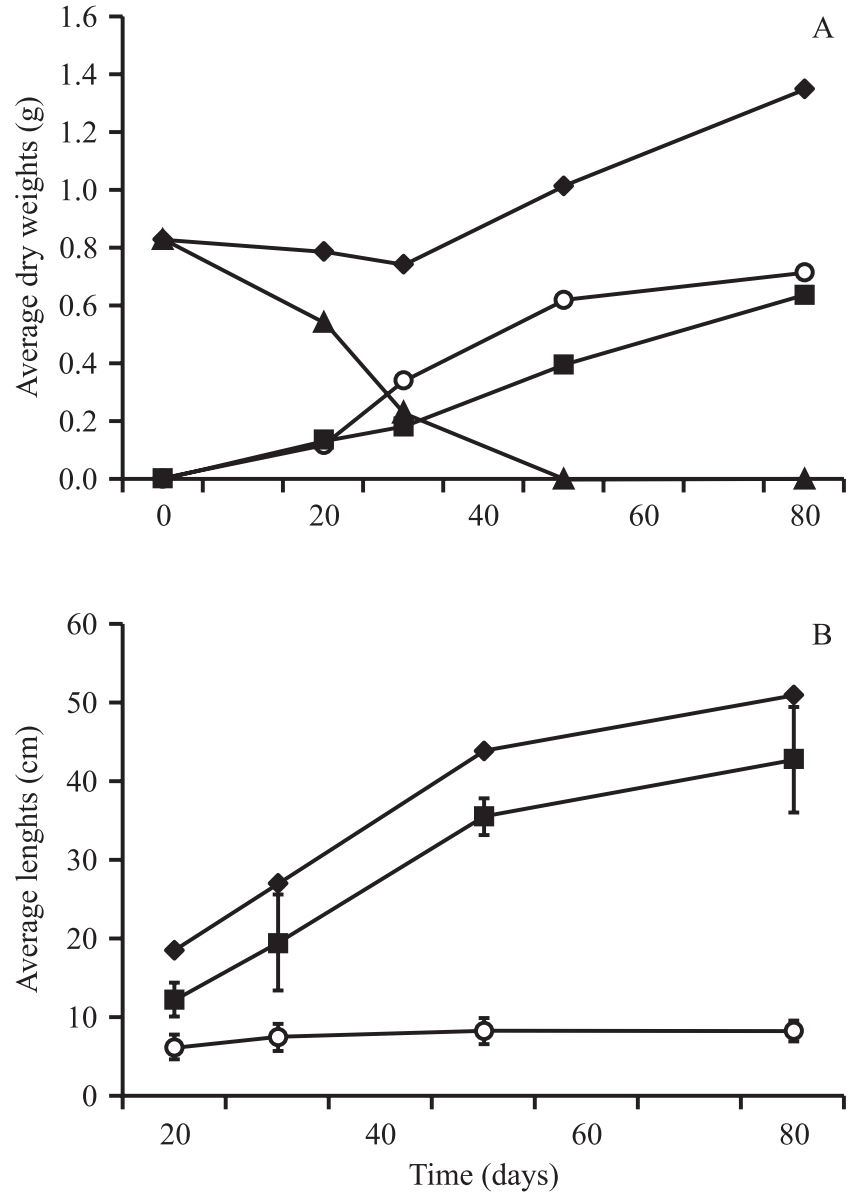

Figure 1. Average dry weights of the roots, cotyledons, shoots and of the entire plants (A), and average lengths of the roots, shoots and of the entire plants (B) of Copaifera langsdorffii grown on soil substrates under natural conditions between the months of April to July/2009. Vertical bars, whenpresent, indicate the standarddeviations. $N=20$ seedlings per date point $(--=$ Total; $-\circ-=$ Shoot; $-\leftarrow=$ Cotyledon; - $=$ Root).

alata demonstrated the smallest average germination time, it also had the smallest average time required for the opening of the first leaf pair (TLO), as well as a more uniform initial growth (as judged by the small standard deviation of TLO) (table 2).

The biomasses of the shoot parts of both $C$. langsdorffii and D. alata increased without significant increase in plant height, indicating a greater initial investment in branching and leaf expansion. The reduction in the weight of the cotyledons in both species underline their principal function as food reserve organs, probably supporting shoot expansion as well as root elongation and lateral root differentiation (figures 1 and 2).

Kielmeyera coriacea did not show opening of the first leaf in any of the individuals examined during 

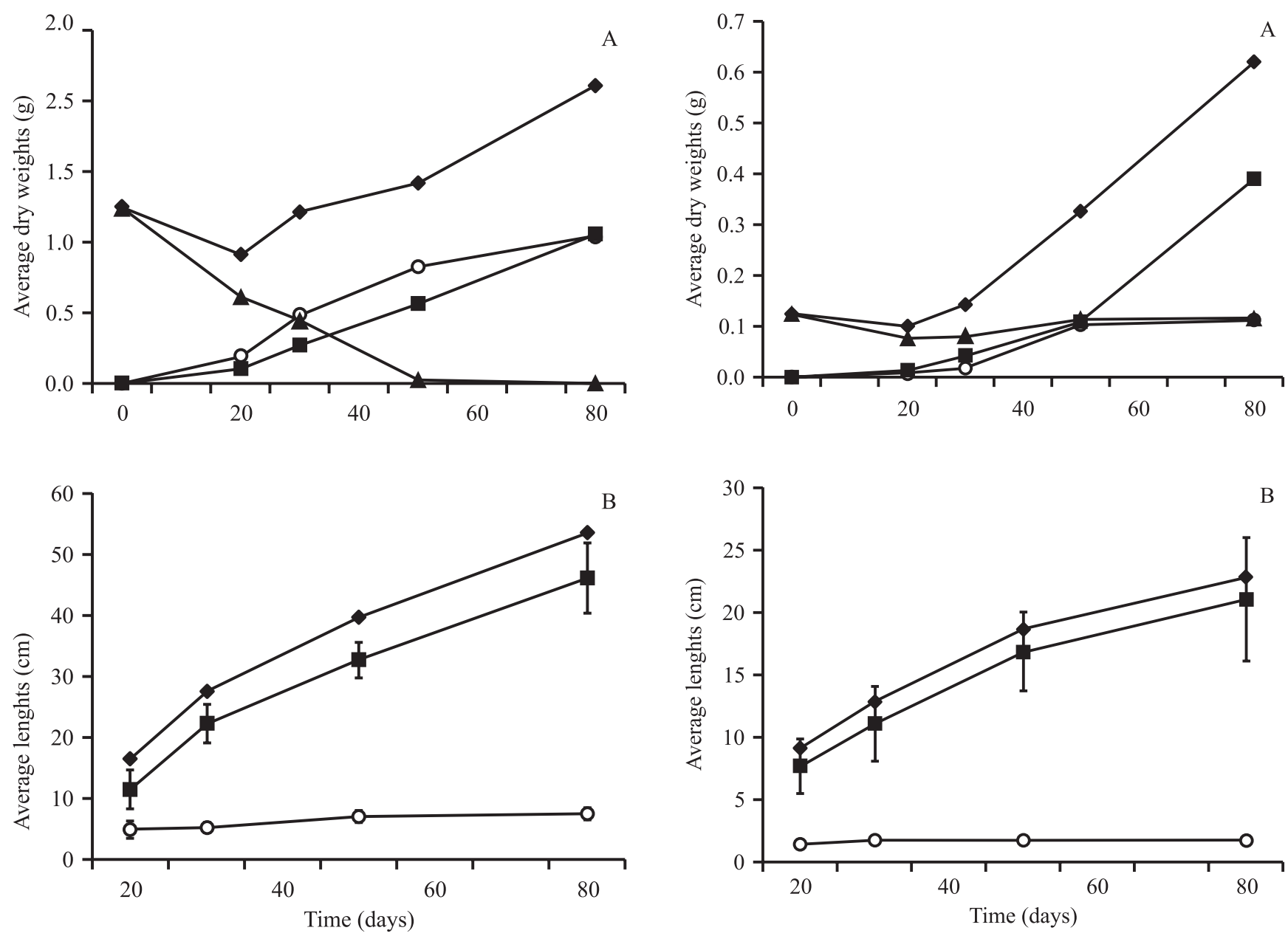

Figure 2. Average dry weights of the roots, cotyledons, shoots and of the entire plants (A), and average lengths of the roots, shoots and of the entire plants (B) of Dipteryx alata grown on soil substrates under natural conditions between the months of April to July/2009. Vertical bars, when present, indicate the standard deviations. $N=20$ seedlings per date point. $(--=$ Total; $-\mathrm{O}=$ Shoot; $\leftarrow-=$ Cotyledon; $-\mathbf{r}=$ Root).

the first 80 days of growth, which made it impossible to calculate its TLO. This was probably due to the photosynthetic functions of the cotyledons (which remained green, intact, moderately thick, and attached to the seedlings during the entire experimental period) (figure 3). As such, it can be concluded that these organs were the principal plant structures responsible for the growth of the root system. The size and biomass of the shoot parts (the cotyledons) remained virtually the same over the entire period of seedling growth.

Morphologically, the root system presented a pivotal and large root, with long and thin lateral roots, these being more numerous in the central region of the main root. The region near the root/stem transition started to

Figure 3. Average dry weights of the roots, cotyledons, shoots and of the entire plants (A), and average lengths of the roots, shoots and of the entire plants (B) of Kielmeyera coriacea grown on soil substrates under natural conditions between the months of April to July/2009. Vertical bars, when present, indicate the standard deviations. $N=20$ seedlings per date point. $\left(--=\right.$ Total; $-\mathrm{O}=$ Shoot; $\_-=$Cotyledon; $\rightarrow-$ Root $)$.

intumesce as early as 30 days after germination in some individuals, and root intumescence was easily visible in all individuals after 50 days of initial growth, suggesting the formation of xylopodium. Under field conditions, six month-old individuals of $K$. coriacea were shown to present well-developed xylopodium (Oliveira \& Silva, 1993), which represents an important strategy for the survival of young plants during the dry season in the Cerrado (Labouriau 1963).

The cotyledons of $D$. alata and C. langsdorffii acted mainly as reserve organs (Ressel et al. 2004), while those of $K$. coriacea acted mainly as photosynthetic organs (Ressel et al. 2004) - this strategy being associated with the more open savanna physiognomies of Cerrado biome 
(Nardoto et al. 1998). The predominantly photosynthetic function of the cotyledons of $K$. coriacea may be among the factors that make the establishment of this species rather rare in forest environments in the Cerrado biome (Silva Júnior 2005) - as light availability in the forest understorey is quite reduced at soil level when compared to open savanna physiognomies (Nardoto et al. 1998). By contrast, individuals of $C$. langsdorffi and D. alata, whose cotyledons function predominantly as reserve organs, can be found in forest physiognomies of the Cerrado biome, as the gallery forests, dry forests, and Cerradão (Cavalcanti \& Ramos 2001, Silva Júnior 2005).

In summary, D. alata and C. langsdorffii seedlings show similar shoot and root biomasses while $K$. coriacea seedlings have greater root than shoot biomasses, with precocious formation of xylopodium. For the three species the root length was at least four times larger than the shoot length. The higher investment in root length than in root biomass in the first 80 days of growth was noticeable, and suggests an strategy to ensure access to water instead of to establish reserves in the root system. This growth pattern has been for a long time considered as a survival strategy among plants occurring in environments subjected to recurring water-stress conditions, such as the savanna physiognomies of the Cerrado biome (Labouriau 1963).

Acknowledgments - The first author thanks CNPq for the Iniciação Científica (Pibic/SEP/UnB) grant. Part of this project was funded with resources from FAP-DF (process $\mathrm{n}^{\mathrm{o}}$ 193.000.424/2008), and from Capes (Capes/PNADB).

\section{REFERENCES}

Almeida SP, Proença CEB, Sano SM, Ribeiro FJ. 1998. Cerrado: espécies vegetais úteis. Embrapa, Planaltina.

Cavalcanti TB, Ramos AE. 2001. Flora do Distrito Federal, Brasil. Embrapa, Brasília, v.1.

Coutinho LM. 1978. O conceito de Cerrado. Revista Brasileira de Botânica 1:17-23.

Doussi MA, Thanos CA. 2002. Ecophysiology of seed germination in Mediterranean geophytes. 1. Muscari spp. Seed Science Research 3:193-201.

Eiten G. 1972. The Cerrado vegetation of Brazil. Botanical Review 38:201-341.

Ferreira AG, Cassol B, Rosa SGT, Silveira TS, Stival AL, Silva AA. 2001. Germinação de sementes de Asteraceae nativas no Rio Grande do Sul, Brasil. Acta Botanica Brasilica 15:231-242.

Haridasan M. 2000. Nutrição mineral de plantas nativas do cerrado. Revista Brasileira de Fisiologia Vegetal 12: 54-64.
Hoffmann WA. 2000. Post-establishment seedling success in the Brazilian Cerrado: a comparison of savanna and forest species. Biotropica 32:62-69.

Hoffmann WA, Orthen B, Franco AC. 2004. Constraints to seedling success of savanna and forest trees across the savanna-forest boundary. Oecologia 140:252-260.

Inmet - Instituto Nacional de Metereologia. 2009, 20 de agosto. Dados da estação automática: Brasília, DF. http://www.inmet.gov.br. (accessed 2011 Dec 10).

Kanegae MF, Braz V, Franco AC. 2000. Efeitos da seca sazonal e disponibilidade de luz na sobrevivência e crescimento de Bowdichia virgilioides em duas fitofisionomias típicas dos cerrados do Brasil Central. Revista Brasileira de Botânica 23:459-468.

Kitajima K. 1994. Relative importance of photosynthetic traits and allocation patterns as correlates of seedlings shade tolerance of 13 tropical trees. Oecologia 98: 419-428.

Labouriau LG. 1983. Agerminação das sementes. Organização dos Estados Americanos - OEA, Washington.

Labouriau LG, Valio IFM, Salgado-Laboriau ML, Handro W. 1963. Nota sobre a germinação de sementes de plantas de cerrado em condições naturais. Revista Brasileira de Biologia 23:227-237.

Leck MA, Parker VT, Simpson R. 1989. Ecology of soil seed banks. Academic Press, New York.

Melo FPL, Neto AVA, Simabukuru EA, Tabarelli M. 2004. Recrutamento e estabelecimento de plântulas In Germinação: do básico ao aplicado (AG Ferreira, F Borghetti, orgs.). ArtMed, Porto Alegre, p.237-250.

Moreira AG, Klink CA. 2000. Biomass allocation and growth of tree seedlings from two contrasting Brazilian savannas. Ecotropicos 13:43-51.

Nardoto GB, Souza MP, Franco AC. 1998. Estabelecimento e padrões sazonais de produtividade de Kielmeyera coriacea (Spr.) Mart. nos cerrados do Planalto Central: efeitos do estresse hídrico e sombreamento. Revista Brasileira de Botânica 21:313-319.

Oliveira Filho AT, Ratter JA. 2002. Vegetation physiognomies and woody flora of the Cerrado Biome. In The Cerrados of Brazil: ecology and natural history of a neotropical savanna. (PS Oliveira, RJ Marquis, eds.). Columbia University Press, New York, p.121-140.

Oliveira PE, Silva JCS. 1993. Reproductive biology of two species of Kielmeyera (Guttiferae) in the Cerrados of Central Brazil. Journal of Tropical Biology 9:67-79.

Ooi MK, Auld TD, Denham AJ. 2009. Climate change and bet-hedging: interactions between increased soil temperatures and seed bank persistence. Global Change Biology 15:2375-2386.

Ressel K, Guilherme FAG, Schiavini I, Oliveira PE. 2004. Ecologia morfo-funcional de plântulas de espécies arbóreas da Estação Ecológica do Panga, Uberlândia, Minas Gerais. Revista Brasileira de Botânica 27: 311-323. 
Ribeiro JF, Walter BMT. 2008. As principais fitofisionomias do bioma Cerrado. In Cerrado: ecologia e flora (SM Sano, SP Almeida, JF Ribeiro, eds.). Embrapa Informação Tecnológica, Brasília, v.1, p.151-212.

Saatkamp A, Affre L, Dutoit A, Poschlod P. 2011. Germination traits explain soil seed persistence across species: the case of Mediterranean annual plants in cereal fields. Annals of Botany 107:415-426.

Salgado MAS, Rezende AV, Felfili JM, Franco AC, Sousa-Silva JC. 2001. Crescimento e repartição de biomassa em plântulas de Copaifera langsdorffi Desf. submetidas a diferentes níveis de sombreamento em viveiro. Brasil Florestal 70:13-21.

Santana DG, Ranal, MA. 2004. Análise da germinação - um enfoque estatístico. Editora Universidade de Brasília, Brasília.
Silva LCR, Sternberg L, Haridasan M, Hoffmann WA, Miralles-Wilhelm F, Franco AC. 2008. Expansion of gallery forests into central Brazilian savannas. Global Changes Biology 14:2108-2118.

Silva Júnior MC. 2005. 100 árvores do cerrado: guia de campo. Rede de Sementes do Cerrado, Brasília.

Venable DL. 2007. Bet hedging in a guild of annual deserts. Ecology 88:1086-1090.

Villela FA, Peres WB. 2004. Coleta, beneficiamento e armazenamento. In Germinação: do básico ao aplicado (AG Ferreira, F Borghetti, orgs.). Artmed Editora, Porto Alegre, v.1, p.265-282.

Zaidan LBP, Carreira RC. 2008. Seed germination in Cerrado species. Brazilian Journal of Plant Physiology 20: 167-181. 